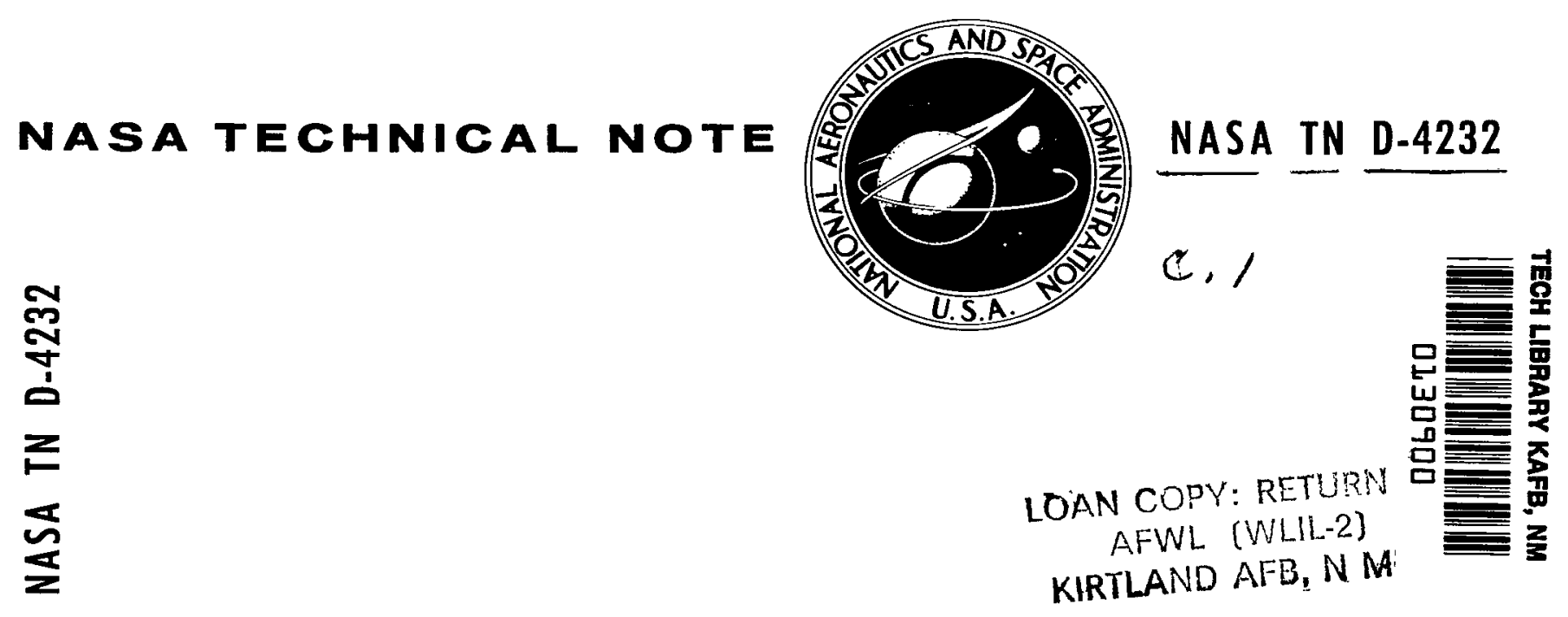

\title{
ELASTIC DISPLACEMENTS FOR VARIOUS EDGE-CRACKED PLATE SPECIMENS
}

by Bernard Gross, Ernest Roberts, Jr., and Jobn E. Srawley

Lewis Research Center

Cleveland, Obio

NATIONAL AERONAUTICS AND SPACE ADMINISTRATION - WASHINGTON, D. C. - NOVEMBER 1967 
ELASTIC DISPLACEMENTS FOR VARIOUS EDGE-CRACKED PLATE SPECIMENS

By Bernard Gross, Ernest Roberts, Jr., and John E. Srawley Lewis Research Center Cleveland, Ohio

\section{NATIONAL AERONAUTICS AND SPACE ADMINISTRATION}

For sale by the Clearinghouse for Federal Scientific and Technical Information Springfield, Virginia 22151 - CFSTI price $\$ 3.00$ 


\title{
ELASTIC DISPLACEMENTS FOR VARIOUS EDGE-CRACKED PLATE SPECIMENS
}

\author{
by Bernard Gross, Ernest Roberts, Jr., and John E. Srawley \\ Lewis Research Center
}

\section{SUMMARY}

The relative displacement per unit load of two conjugate points is used as a quantitative indicator of crack extension in plane strain fracture toughness $\mathrm{K}_{\mathrm{Ic}}$ tests. The necessary displacement data are presented here in dimensionless form for five types of single-edge-crack specimens: three-point bending, pure bending, remote axial tension, and eccentric tension of compact rectangular and tapered varieties. The results were obtained by a boundary collocation method of elastic analysis and are highly precise in themselves. The accuracy with which they apply to actual specimens depends on the extent to which the assumed boundary conditions are equivalent to the actual load distributions. Reasonably good agreement was obtained with three sets of existing experimental data, and this agreement is sufficient for $\mathrm{K}_{\mathrm{Ic}}$ test purposes. For gage points located on the specimen edge, the results show low sensitivity to small variations in gage location.

\section{INTRODUCTION}

In plane strain fracture toughness $\mathrm{K}_{\mathrm{Ic}}$ testing, the relative displacement per unit load $\mathrm{v}_{\mathrm{y}} / \mathrm{P}$ of two conjugate points is used as a quantitative indicator of crack extension during the test (refs. 1 to 3 ) The relation between $\mathrm{v}_{\mathrm{y}} / \mathrm{P}$ and relative crack length $\mathrm{a} / \mathrm{W}$ depends on the type of specimen employed. The relations for various specimens are determined by linear elastic strain analysis, or by direct experimental measurements in which slots are used to simulate cracks. This report presents $v_{y} / \mathbf{P}$ data obtained by a boundary collocation method of analysis for several types of single-edge-crack plate specimens. The use of these specimens in $K_{\mathrm{Ic}}$ testing has been explained by Brown and Srawley (refs. 1 and 2).

The following types of loading were investigated (figs. 1 and 2): three-point bending having a span to width ratio of 4 , pure bending, remote axial tension, and eccentric ten- 


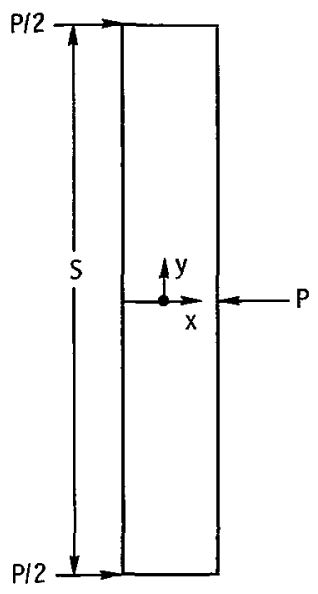

Three-point bend specimen $(S / W=4)$

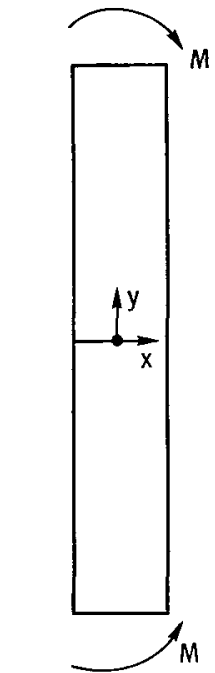

Pure bend specimen

(a) Three types of loading.

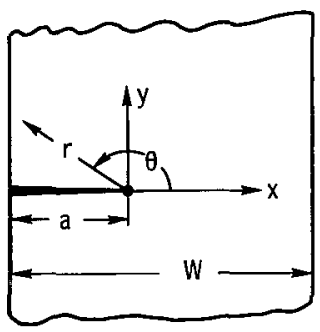

(b) Common geometric configuration.

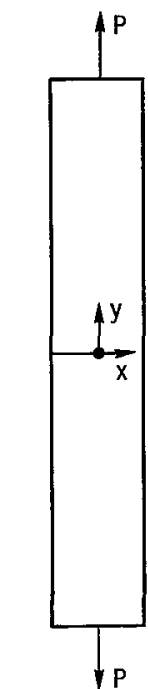

Remote axialtension specimen

Figure 1. - Bending- and axial-tension plate specimens.

sion (compact rectangular and tapered varieties of specimens). The results are given in the form of tables of a dimensionless displacement coefficient as a function of the major variable, relative crack length $\mathrm{a} / \mathrm{W}$, and of the secondary variables $\mathrm{x} / \mathrm{W}$ and $\mathrm{y} / \mathrm{W}$ which represent the gage point locations in relation to the crack tip.

Displacement measurement for detection of crack extension in a $\mathrm{K}_{\mathrm{Ic}}$ test should not be confused with measurements of specimen compliance (reciprocal stiffness) for determination of energy release rates (ref. 1). The intent of a compliance experiment is to determine the work done by the loading forces, and the displacement measured must be chosen appropriately. For evaluation of crack extension, any convenient gage points can be used for the displacement measurement. The most sensitive positions are those close to the crack, which are precisely the least suitable for compliance when the specimen is remotely loaded. However, for the eccentric tension specimens discussed in this report, the gage point positions that are convenient for crack extension detection are also suitable for compliance determinations. 


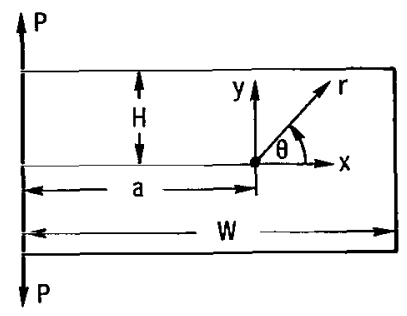

(a) Compact rectangular.

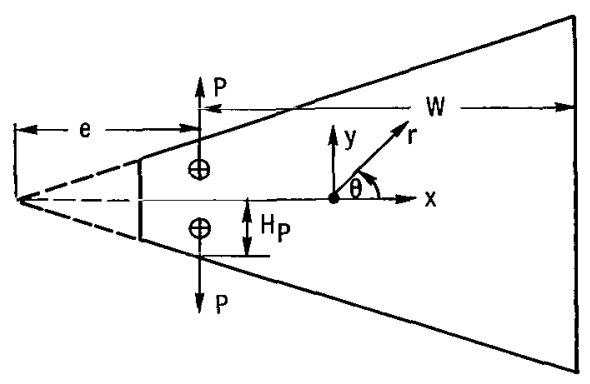

(b) Tapered.

Figure 2. - Eccentric tension plate specimens.

\section{SYMBOLS}

a

B

$\mathrm{d}_{2 \mathrm{n}}, \mathrm{d}_{2 \mathrm{2n}-1}$

E

e

$\mathrm{H}$

$\mathrm{H}_{\mathrm{p}}$

$\mathbf{K}$

$\mathrm{K}_{\mathrm{Ic}}$

M

$\mathbf{P}$

$\mathbf{r}$ crack length

specimen thickness

coefficients of Williams stress function

Young's modulus

distance from wedge tip to line of load application

unifor $m$ depth of nontapered split arm

depth of tapered split arm at load line

stress intensity factor of crack tip elastic stress field

plane strain fracture toughness, measured in terms of the opening mode stress intensity factor $K_{I}$ in units of (Stress) $\times(\text { Length) })^{1 / 2}$ (see refs.

1 and 2)

bending moment

load

polar coordinates referred to crack tip 


$\begin{array}{ll}\mathbf{S} & \text { span } \\ \mathrm{U} & \text { displacement in radial direction } \\ \mathrm{u}_{\mathrm{x}} & \text { displacement in } \mathrm{x} \text {-direction } \\ \mathrm{V} & \text { displacement in tangential direction } \\ \mathrm{v}_{\mathrm{y}} & \text { displacement in } \mathrm{y} \text {-direction between } \pm \mathrm{y} \text { locations } \\ \mathrm{W} & \text { specimen width } \\ \mathrm{x}, \mathrm{y} & \text { Cartesian coordinate system referred to crack tip } \\ \theta & \text { polar coordinate referred to crack tip } \\ \nu & \text { Poisson's ratio } \\ \varphi & \text { harmonic function in displacement equation } \\ \mathrm{X} & \text { Airy stress function }\end{array}$

\section{ANALYSIS}

The method of analysis is described in some detail by Gross and coauthors (refs. 4 to 8). Its earliest use in solid mechanics is by Barta (ref. 9). Considerable detail is given by Green (ref. 10) and Howland and Knight (ref. 11). The method is called variously "boundary collocation" and "point matching". Briefly, it consists of truncating a series solution to the appropriate partial differential equation, and making use of the boundary values at a finite number of points to evaluate its coefficients. It can be shown (ref. 12) that the biharmonic equation in terms of an Airy stress function properly describes the plane elastic problem. It is convenient to use the Williams stress function for our analysis (refs. 13 and 14). It is an Airy stress function, it identically satisfies the biharmonic equation, and it identically satisfies the boundary conditions along the crack surface.

The equation to be solved is

$$
\nabla^{4} x=0
$$

where the origin of the polar coordinate system is the crack tip (fig. 3). The solution given by Williams is 
$x(r, \theta)=\sum_{n=1,2,3}^{\infty}\left\{(-1)^{n-1} d_{2 n-1} r^{n+1 / 2}\left[-\cos \left(n-\frac{3}{2}\right) \theta+\frac{2 n-3}{2 n+1} \cos \left(n+\frac{1}{2}\right) \theta\right]\right.$

$$
\left.+(-1)^{\mathrm{n}} \mathrm{d}_{2 \mathrm{n}} \mathrm{r}^{\mathrm{n}+1}[-\cos (\mathrm{n}-1) \theta+\cos (\mathrm{n}+1) \theta]\right\}
$$

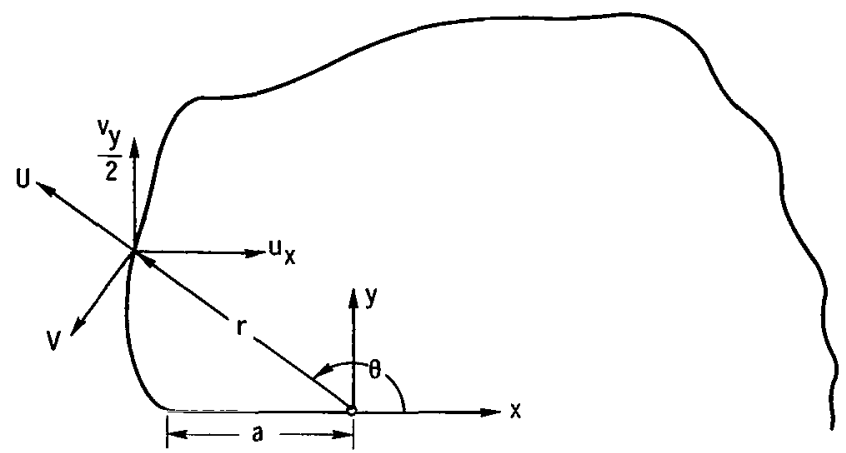

Figure 3. - Geometry defining displacements in $x$ - and $y$-directions.

The displacements in terms of the stress function and a harmonic function $\varphi(r, \theta)$ are given by Williams (refs. 13 and 14) and Coker and Filon (ref. 15). In infinite series form they become

$$
\begin{aligned}
& \varphi(\mathrm{r}, \theta)=\sum_{\mathrm{n}=1,2,3 \ldots}^{\infty} \mathrm{r}^{\mathrm{n}-1}(-1)^{\mathrm{n}+1} 4\left[\frac{-\mathrm{d}_{2 \mathrm{n}-1}}{\mathrm{r}^{1 / 2}} \frac{\sin \left(\mathrm{n}-\frac{3}{2}\right) \theta}{\mathrm{n}-\frac{3}{2}}+\frac{\mathrm{d}_{2 \mathrm{n}}}{\mathrm{n}-1} \sin (\mathrm{n}-1) \theta\right] \\
& 2 \mu \mathrm{V}(\mathrm{r}, \theta)=-\frac{1}{\mathrm{r}} \frac{\partial \mathrm{X}}{\partial \mathrm{r}}+(1-\sigma) \mathrm{r}^{2} \frac{\partial \varphi}{\partial \theta} \\
& 2 \mu \mathrm{U}(\mathbf{r}, \theta)=-\frac{\partial \mathbf{x}}{\partial \mathbf{r}}+(1-\sigma) \mathbf{r} \frac{\partial \varphi}{\partial \theta}
\end{aligned}
$$


where for plane stress $\sigma=\nu /(1+\nu)$, for plain strain $\sigma=\nu$, and for either plane stress or plane strain $\mu=\mathrm{E} /[2(1+\nu)]$. The resulting displacement equations are

$$
\begin{array}{r}
\mathrm{v}(\mathrm{r}, \theta)=\frac{1}{2 \mu} \sum_{\mathrm{n}=1,2,3 \ldots}\left\{\begin{array}{r}
(-1)^{\mathrm{n}} \mathrm{d}_{2 \mathrm{n}-1} \mathrm{r}^{\mathrm{n}-1 / 2}\left[\left(\frac{5}{2}+\mathrm{n}-4 \sigma\right) \sin \left(\mathrm{n}-\frac{3}{2}\right) \theta-\left(\frac{2 \mathrm{n}-3}{2}\right) \sin \left(\mathrm{n}+\frac{1}{2}\right) \theta\right] \\
\left.+(-1)^{\mathrm{n}} \mathrm{d}_{2 \mathrm{n}} \mathrm{r}^{\mathrm{n}}[(\mathrm{n}-\sigma) \sin (\mathrm{n}-1) \theta-(\mathrm{n}+1) \sin (\mathrm{n}+1) \theta]\right\}
\end{array}\right. \\
\mathrm{U}(\mathrm{r}, \theta)=\frac{1}{2 \mu} \sum_{\mathrm{n}=1,2,3 \ldots}\left\{\begin{array}{r}
\sum^{n} \mathrm{r}^{\mathrm{n}-1 / 2} \mathrm{~d}_{2 \mathrm{n}-1}\left[\left(\frac{7}{2}-\mathrm{n}-4 \sigma\right) \cos \left(\mathrm{n}-\frac{3}{2}\right) \theta+\left(\mathrm{n}-\frac{3}{2}\right) \cos \left(\mathrm{n}+\frac{1}{2}\right) \theta\right] \\
\left.+(-1)^{\mathrm{n}+1} \mathrm{~d}_{2 \mathrm{n}}[(3-\mathrm{n}-4 \sigma) \cos (\mathrm{n}-1) \theta+(\mathrm{n}+1) \cos (\mathrm{n}+1) \theta]\right\}
\end{array}\right.
\end{array}
$$

For the special case of $\theta=\pi$, it can be deduced from these equations that the displacements for plane stress are independent of Poisson's ratio $\nu$, and that the displacements for plane strain are equal to $\left(1-\nu^{2}\right)$ times those for plane stress. Since this simplification applies to nearly all the results obtained, it was convenient to compute the results for plane stress.

The displacements in the $\mathrm{x}$ - and $\mathrm{y}$-directions (fig. 3) are

$$
\begin{gathered}
\mathrm{u}_{\mathrm{x}}=\mathrm{U} \cos \theta-\mathrm{V} \sin \theta \\
\mathrm{v}_{\mathrm{y}}=2(\mathrm{U} \sin \theta+\mathrm{V} \cos \theta)
\end{gathered}
$$

It is to be noted that $v_{y}$ as defined in the preceding expression is the displacement indicated by a gage mounted across the crack, that is, the relative displacement of a pair of conjugate points.

The number of terms in the series, and hence the number of boundary points satisfied, was progressively increased until negligible changes occurred in the values of the displacement. The relation between calculated displacement and the number of terms in 


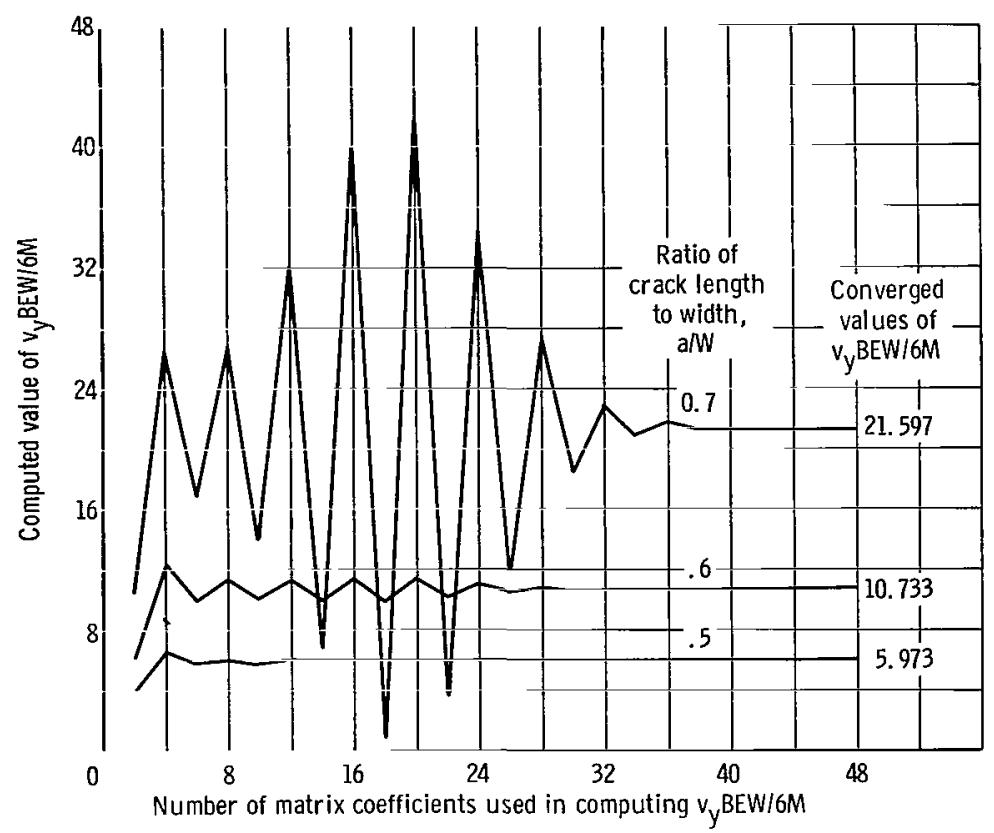

Figure 4. - Typical variation of dimensionless displacement coefficient $v_{y} B E W / 6 M$ as function of number of coefficients used in computation. Displacements are for three-point bend specimens computed at specimen crack edge.

the series is shown graphically in figure 4 for one specimen configuration.

All quantities used in the analysis were made dimensionless. Hence, all crack lengths are relative to specimen width $\mathrm{a} / \mathrm{w}$, all coordinates are relative to specimen width $\mathrm{x} / \mathrm{W}$ and $\mathrm{y} / \mathrm{W}$, and all displacements are relative to elastic modulus, specimen thickness, and either load or moment per unit depth $W, v_{y} B E / P$ and $v_{y} E B W / 6 M$.

\section{RESULTS AND DISCUSSION}

Dimensionless displacement coefficients for plane stress are tabulated for values of the relative crack length $\mathrm{a} / \mathrm{W}$ up to 0.7 in tables $I$ to $V I$. The results for three-point bend specimens $\mathrm{S} / \mathrm{W}=4$ (tables $\mathrm{I}$ and II) are more detailed than the others because these specimens are of particular current interest for standardized $\mathrm{K}_{\mathrm{Ic}}$ measurement (ref. 2). Tables I and II show the displacements for different gage point locations, respectively; along the crack, and along the specimen edge normal to the crack. The displacement is considerably more sensitive to position along the crack than along the specimen edge normal to the crack. For this reason, it is desirable in practice to locate the gage on the edge of the specimen. However, in $\mathrm{K}_{\mathrm{Ic}}$ measurement, the factor needed is the derivative of the logarithm of the displacement coefficient with respect to the logarithm of 
the relative crack length (ref. 1$)^{1}$, and this factor is less sensitive to gage location than is the displacement coefficient itself. Therefore, the results obtained in $\mathrm{K}_{\mathrm{Ic}}$ tests will show low sensitivity to small variations in gage location.

As a matter of interest, the displacements parallel to the crack $u_{x}$ are given in table $I$ as well as the displacements normal to the crack. These lengthwise displacements are comparatively small and are not of any particular interest.

TABLE I. - DIMENSIONLESS DISPLACEMENTS ALONG CRACK FOR

THREE-POINT BEND SPECIMENS (S/W = 4) (PLANE STRESS)

\begin{tabular}{|c|c|c|c|c|c|c|c|}
\hline \multicolumn{2}{|c|}{ Gage location } & \multicolumn{6}{|c|}{$a / w$} \\
\hline \multirow[t]{2}{*}{$\mathrm{x} / \mathrm{w}$} & \multirow[t]{2}{*}{$y / w$} & \multicolumn{2}{|c|}{0.3} & \multicolumn{2}{|c|}{0.5} & \multicolumn{2}{|c|}{0.7} \\
\hline & & $\mathrm{EBv}_{\mathrm{y}} \mathrm{W} / 6 \mathrm{M}$ & $E B u_{x} W / 6 M$ & $E B v_{y} W / 6 M$ & $E B u_{x} W / 6 M$ & $\mathrm{EBv}_{\mathrm{y}} \mathrm{W} / 6 \mathrm{M}$ & $\mathrm{EBu}_{\mathrm{x}} \mathrm{W} / 6 \mathrm{M}$ \\
\hline$-a / 32 W$ & \pm 0 & 0.316 & 0.0012 & 0.722 & -0.0024 & 1.948 & -0.0230 \\
\hline$-a / 16 w$ & 1 & .450 & .0025 & 1.041 & -.0045 & 2.876 & -.0436 \\
\hline$-a / 8 w$ & & .644 & .0052 & 1.525 & -.0080 & 4.391 & -.0789 \\
\hline$-a / 4 w$ & & .933 & .0107 & 2.298 & -.0120 & 7.050 & -.1303 \\
\hline$-a / 2 W$ & & 1.377 & .0218 & 3.611 & ----- & 12.019 & -.1802 \\
\hline$-a / w$ & 1 & 2.099 & ----- & 5.972 & $\ldots \ldots$ & 21.597 & ------- \\
\hline
\end{tabular}

The last line in table II lists experimental results by Fisher (ref. 3) for comparison. The experimental results are somewhat lower than the computed results for plane stress, but not as much as by the factor $\left(1-\nu^{2}\right)$ for $v=0.3$. Thus, the experimental results are bracketed by the computed results for plane stress and those for plane strain (to a close approximation). This would be expected since the region near the crack tip in the actual specimen approaches a state of plain strain, whereas regions remote from the crack tip are in a state of plane stress. The two-dimensional analysis is not capable of producing closer agreement with the experimental results. Experimental results are also compared with computed results in table III for pure bending, and the differences are similar to those for three-point bending. The displacements are greater for pure bending than for three-point bending because of the different bending moment distributions.

Table IV gives results for single-edge-cracked specimens under remote axial tension on the assumption of uniform stress distribution at a distance not less than $0.8 \mathrm{~W}$ from the crack (ref. 4). These results are intended to apply to pin-loaded specimens with pin centers not less than $3 \mathrm{~W}$ apart.

${ }^{1}$ For example, for remote axial tension, the factor is $\left[d \log \left(v_{y} E B / P\right) / d \log (a / W)\right]$ which is equal to $\left[(a / w) /\left(v_{y} E B / P\right)\right]\left[d\left(v_{y} E B / P\right) / d(a / w)\right]$ as in fig. 40 of ref. 1 . 
TABLE II. - DIMENSIONLESS DISPLACEMENTS AT EDGE FOR THREEPOINT BEND SPECIMENS (PLANE STRESS) WITH COMPARATTVE EXPERIMENTAL RESULTS $(\mathrm{S} / \mathrm{W}=4)$

\begin{tabular}{|c|c|c|c|c|c|c|c|c|}
\hline \multicolumn{2}{|c|}{ Gage location } & \multicolumn{6}{|c|}{$a / w$} & \multirow[t]{3}{*}{ Source } \\
\hline $\mathrm{x} / \mathrm{W}$ & $\mathrm{y} / \mathrm{w}$ & 0.2 & 0.3 & 0.4 & 0.5 & 0.6 & 0.7 & \\
\hline & & \multicolumn{6}{|c|}{$\mathrm{EBv}_{\mathrm{y}} \mathrm{W} / 6 \mathrm{M}$} & \\
\hline \multirow[t]{5}{*}{$-a / w$} & \pm 0 & 1.184 & 2.091 & 3.520 & 5.973 & 10.733 & 21.597 & Collocation \\
\hline & \pm .10 & 1.217 & 2.109 & 3.529 & 5.987 & 10.751 & 21.625 & Collocation \\
\hline & \pm .20 & 1.453 & 2.293 & 3.696 & 6.154 & 10.940 & 21.865 & Collocation \\
\hline & \pm .50 & 2.385 & 3.082 & 4.388 & 6.817 & 11.632 & 22.656 & Collocation \\
\hline & \pm .10 & $--\infty-$ & 1.94 & 3.46 & 5.60 & 9.74 & 19.9 & $\begin{array}{c}\text { Fisher, et al. } \\
\text { (ref. 3) }\end{array}$ \\
\hline
\end{tabular}

TABLE III. - DIMENSTONLESS DISPLACEMENTS AT EDGE FOR PURE BEND SPECIMENS (PLANE STRESS) WITH COMPARATIVE

EXPERIMENTAL RESULTS

\begin{tabular}{|c|c|c|c|c|c|c|c|c|}
\hline \multicolumn{2}{|c|}{ Gage location } & \multicolumn{6}{|c|}{$a / w$} & \multirow[t]{3}{*}{ Source } \\
\hline \multirow[t]{2}{*}{$x / w$} & $\mathrm{y} / \mathrm{w}$ & 0.2 & 0.3 & 0.4 & 0.5 & 0.6 & 0.7 & \\
\hline & & \multicolumn{6}{|c|}{$\mathrm{EBv}_{\mathrm{y}} \mathrm{W} / 6 \mathrm{M}$} & \\
\hline \multirow{2}{*}{$-a / w$} & \pm 0 & 1.260 & 2.241 & 3.763 & 6.368 & 11.354 & 22.575 & Collocation \\
\hline & \pm .10 & 1.20 & 2.17 & 3.69 & 6.00 & 10.80 & 21.40 & $\begin{array}{c}\text { Fisher, et al. } \\
\text { (ref. 3) }\end{array}$ \\
\hline
\end{tabular}

TABLE IV . - DIMENSIONLESS DISPLACEMENTS AT EDGE FOR REMOTE AXIAL TENSTON SPECIMENS (PLANE STRESS)

\begin{tabular}{|l|l|c|c|c|c|c|c|} 
Gage location & \multicolumn{5}{|c|}{$\mathrm{a} / \mathrm{W}$} \\
$\mathrm{x} / \mathrm{W}$ & $\mathrm{y} / \mathrm{W}$ & 0.2 & 0.3 & 0.4 & 0.5 & 0.6 & 0.7 \\
& & \multicolumn{5}{|c|}{$\mathrm{EBv}_{\mathrm{y}} / \mathrm{P}$} \\
$-\mathrm{a} / \mathrm{W}$ & \pm 0 & 1.440 & 2.806 & 5.217 & 9.881 & 19.900 & 44.100 \\
\hline
\end{tabular}


Tables V and VI give results for various compact tension specimens which are eccentrically loaded at positions close to the crackline and to the specimen edge (ref. 8). Table V includes a comparison with experimental results from Bush and Wilson (ref. 16), which are in satisfactory agreement with the computed results in spite of the considerable difference of gage point location. It would be expected, however, that this type of specimen would be particularly insensitive to gage location along the specimen edge.

TABLE V. - DIMENSIONLESS DISPLACEMENTS AT LOAD LINE

FOR ECCENTRICALLY LOADED COMPACT RECTANGULAR

TENSION SPECIMENS (PLANE STRESS)

\begin{tabular}{|c|c|c|c|c|c|c|c|c|}
\hline \multicolumn{2}{|c|}{ Gage location } & \multirow[t]{3}{*}{$\mathrm{W} / \mathrm{H}$} & \multicolumn{5}{|c|}{$a / w$} & \multirow[t]{3}{*}{ Source } \\
\hline \multirow[t]{2}{*}{$\mathrm{x} / \mathrm{w}$} & \multirow[t]{2}{*}{$y / w$} & & 0.3 & 0.4 & 0.5 & 0.6 & 0.7 & \\
\hline & & & \multicolumn{5}{|c|}{$\mathrm{EBv}_{\mathrm{y}} / \mathrm{P}$} & \\
\hline \multirow[t]{4}{*}{$-a / w$} & \multirow[t]{4}{*}{ \pm 0} & $5 / 4$ & 11.813 & 19.277 & 32.140 & 57.335 & 116.031 & \multirow{5}{*}{ Source } \\
\hline & & $5 / 3$ & 14.266 & 22.968 & 37.015 & 63.320 & 122.050 & \\
\hline & & $20 / 11$ & 15.125 & 25.058 & 39.877 & 66.926 & 126.699 & \\
\hline & & $25 / 12$ & 18.075 & 29.473 & 46.229 & 75.234 & 136.966 & \\
\hline \multirow[t]{2}{*}{$\mathrm{x} / \mathrm{w}$} & \multirow[t]{2}{*}{$\mathrm{y} / \mathrm{w}$} & \multirow[t]{2}{*}{$\mathrm{W} / \mathrm{H}$} & \multicolumn{5}{|c|}{$a / w$} & \\
\hline & & & 0.333 & 0.389 & 0.444 & 0.500 & 0.556 & \\
\hline \multirow[t]{2}{*}{$-a / w$} & \pm 0 & $9 / 4$ & 23.392 & 30.480 & 40.057 & 51.145 & 65.964 & Collocation \\
\hline & \pm .875 & $9 / 4$ & 24.96 & 30.96 & 38.52 & 49.20 & 63.36 & $\begin{array}{c}\text { Bush, Wilson } \\
\text { (ref. 16) }\end{array}$ \\
\hline
\end{tabular}

TABLE VI. - DIMENSIONLESS DISPLACEMENTS AT LOAD

LINE FOR ECCENTRICALLY LOADED TAPERED

TENSION SPECIMENS (PLANE STRESS)

\begin{tabular}{|c|c|c|c|c|c|c|c|c|c|}
\hline \multicolumn{2}{|c|}{ Gage location } & \multirow{3}{*}{$\mathrm{H}_{\mathrm{p}} / \mathrm{e}$} & \multirow[t]{3}{*}{$\mathrm{w} / \mathrm{e}$} & \multicolumn{6}{|c|}{$a / w$} \\
\hline \multirow[t]{2}{*}{$\mathrm{x} / \mathrm{w}$} & \multirow[t]{2}{*}{$\mathrm{y} / \mathrm{w}$} & & & 0.2 & 0.3 & 0.4 & 0.5 & 0.6 & 0.7 \\
\hline & & & & \multicolumn{6}{|c|}{$\mathrm{EBv}_{\mathrm{y}} / \mathrm{P}$} \\
\hline \multirow[t]{3}{*}{$-a / w$} & ${ }_{ \pm 0} 0$ & 0.2 & 3.2 & 162.8 & 312.7 & 474.2 & 641.9 & 810.0 & 985.4 \\
\hline & & 3 & 4.2 & 97.3 & 170.8 & 242.4 & 313.6 & 387.5 & 481.0 \\
\hline & & 4 & 5.0 & 67.0 & 107.8 & 148.3 & 187.3 & 234.9 & 306.3 \\
\hline
\end{tabular}




\section{CONCLUSIONS}

Boundary collocation is a satisfactory procedure for computing elastic displacements (per unit load) for single-edge-crack specimens. The results are highly precise and inexpensive of computer time, so that variations of specimen shape and gage location can be explored at little cost. To do the same experimentally would be quite expensive. The accuracy with which the results apply to actual specimens depends, of course, on the extent to which the assumed boundary conditions are equivalent to the actual load distributions.

Where the present results could be compared with existing experimental results shown in the tables, the agreement is reasonably good and is adequate for plane strain fracture toughness $K_{I c}$ test purposes. The results confirm the expected low sensitivity to small variations in gage point location when these points are on the specimen edge. The sensitivity to change of position of gage point location along the crack is greater.

Lewis Research Center,

National Aeronautics and Space Administration, Cleveland, Ohio, July 13, 1967, 731-21-03-01-22.

\section{REFERENCES}

1. Brown, William F., Jr.; and Srawley, John E. : Plane Strain Crack Toughness Testing of High Strength Metallic Materials. Spec. Tech. Pub. No. 410, ASTM, 1966.

2. Srawley, John E. ; Jones, Melvin H. ; and Brown, William F., Jr.: Determination of Plane Strain Fracture Toughness. Mat. Res. \& Standards, vol. 7, no. 6, June 1967, pp. $262-266$.

3. Fisher, Douglas M.; Bubsey, Raymond T. ; and Srawley, John E. : Design and Use of Displacement Gage for Crack-Extension Measurements. NASA TN D-3724, 1966.

4. Gross, Bernard; Srawley, John E.; and Brown, William F., Jr.: Stress-Intensity Factors for a Single-Edge-Notch Tension Specimen by Boundary Collocation of a Stress Function. NASA TN D-2395, 1964.

5. Gross, Bernard; and Srawley, John E.: Stress-Intensity Factors for Single-EdgeNotch Specimens in Bending or Combined Bending and Tension by Boundary Collocation of a Stress Function. NASA TN D-2603, 1965. 
6. Gross, Bernard; and Srawley, John E.: Stress-Intensity Factors for Three-Point Bend Specimens by Boundary Collocation. NASA TN D-3092, 1965.

7. Gross, Bernard; and Srawley, John E.: Stress-Intensity Factors by Boundary Collocation for Single-Edge-Notch Specimens Subject to Splitting Forces. NASA TN D-3295, 1966.

8. Srawley, John E.; and Gross, Bernard: Stress Intensity Factors for CracklineLoaded Edge-Crack Specimens. Mat. Res. \& Standards, vol. 7, no. 4, Apr. 1967, pp. 155-162. See NASA TN D-3820, 1967.

9. Barta, J.: Über die Näherungsweise Lösung Einiger Zweidimensionaler Elastizitätsaufgaben. Z. Angew. Math. Mech., vol. 17, no. 3, June 1937, pp. 184-185.

10. Green, A. E.: General Bi-Harmonic Analysis for a Plate Containing Circular Holes. Proc. Roy. Soc. London, ser. A, vol. 176, no. 964, Aug. 28, 1940, pp. 121-139.

11. Howland, R. C. J.; and Knight, R. C.: Stress Functions for a Plate Containing Groups of Circular Holes. Phil. Trans. Roy. Soc. London, ser. A, vol. 238, 1940, pp. 357-392.

12. Sokolnikoff, Ivan S.: Mathematical Theory of Elasticity. Second ed., McGraw-Hill Book Co., Inc., 1956.

13. Williams, M. L.: On the Stress Distribution at the Base of a Stationary Crack. J. Appl. Mech., vol. 24, no. 1, Mar. 1957, pp. 109-114.

14. Williams, M. L.: The Bending Stress Distribution at the Base of a Stationary Crack. J. Appl. Mech., vol. 28, no. 1, Mar. 1961, pp. 78-82.

15. Coker, E. G.; and Filon, L. N. G. : A Treatise on Photo-elasticity. Second ed. , Cambridge University Press, 1957.

16. Bush, A. J.; and Wilson, W. K.: Determination of Energy Release Rate for Biaxial Brittle Fracture Specimen. Rep. No. WERL-8844-2, Westinghouse Electric Corp. , Aug. 1964. (Available from DDC as AD-611659.) 
"The aeronautical and space activities of the United States shall be conducted so as to contribute . . to the expansion of buman knowledge of phenomena in the atmosphere and space. The Administration shall provide for the widest practicable and appropriate dissemination of information concerning its activities and the results tbereof."

-National Aeronautics and Space ACt of 1958

\section{NASA SCIENTIFIC AND TECHNICAL PUBLICATIONS}

TECHNICAL REPORTS: Scientific and technical information considered important, complete, and a lasting contribution to existing knowledge.

TECHNICAL NOTES: Information less broad in scope but nevertheless of importance as a contribution to existing knowledge.

TECHNICAL MEMORANDUMS: Information receiving limited distribution because of preliminary data, security classification, or other reasons.

CONTRACTOR REPORTS: Scientific and technical information generated under a NASA contract or grant and considered an important contribution to existing knowledge.

TECHNICAL TRANSLATIONS: Information published in a foreign language considered to merit NASA distribution in English.

SPECIAL PUBLICATIONS: Information derived from or of value to NASA activities. Publications include conference proceedings, monographs, data compilations, handbooks, sourcebooks, and special bibliographies.

TECHNOLOGY UTILIZATION PUBLICATIONS: Information on technology used by NASA that may be of particular interest in commercial and other non-aerospace applications. Publications include Tech Briefs, Technology Utilization Reports and Notes, and Technology Surveys.

Details on the availability of these publications may be obtained from:

SCIENTIFIC AND TECHNICAL INFORMATION DIVISION

NATIONAL AERONAUTICS AND SPACE ADMINISTRATION

Washington, D.C. 20546 